\title{
Isabel Iribarren
}

\section{Jean Gerson, Spiritual Adviser to the Celestines}

Since one thing only is necessary [Luke 10,42], excellent and eternal, it must suffice for the trader searching beautiful pearls and who, having come across one, sells all he has in exchange for it [Mat. 13, 45-46]. This consideration encouraged me to labour more often in the ocean and the prolix waters of the Sacred Scriptures. Thus, today, the $1^{\text {st }}$ October of the year 1425, while I was examining the work of Ubertino [de Casale], as I read again what he says about Simeon's canticle, Luke 2 [29]: Now you are letting your servant go in peace, it seemed to me, at first sight, a very profound consideration on Jesus Christ and the mystery of his peace. And as I examined this doctrine further and in detail, little foxes appeared which do damage to the vines, especially when they bave young grapes [Song 2,15]1.

Thus begins the letter that Jean Gerson, then in exile in Lyon, writes to his younger brother Jean the Celestine, prior of the convent of that city. Jean would have asked for the ex-chancellor's expert advice on the doctrinal content of the Arbor vitae crucifixae Iesu of the Franciscan Ubertino de Casale. Also known by the allusive title of De libris caute legendis, Gerson's letter attempts to guard the monk against the doctrinal traps to which an inattentive reader could fall victim. The Biblical images are not insignificant. Like the trader who searches for the most beautiful pearl, the theologian is capable of discerning the one sufficient truth among the ocean of false doctrines that seduce the inexperienced reader. In the same spirit, Gerson advises his brother to distance himself from Ubertino's joachimite tendencies, whose work "must be read with caution, if not entirely neglected" 2 . Indeed, under the cover of an "eminent Franciscan tradition", those "little foxes" are causing damage to the flourishing vines of mystical theology. In this perspective, the theologian would play a pastoral role on behalf of the

1 "Quia unum est necessarium, optimum et aeternum, sufficere debet quaerenti bonas margaritas ut tandem inveniat unam et venditis omnibus comparet eam. Haec me consideratio permovit facere saepius operationem in mare et in aquis multis sacrae scripturae nominatim hodie, prima octobris anni 1425 dum perscrutatus sum scripta Humbertini relegendo quid super illud canticum Simeonis, Lucae 2: Nunc dimittis servum tuum, notaverit, apparuit mihi, sicut et alias, aspectu perfunctorio, grande nimis et profundum super Iesu Christi et pacis suae mysterio. Et dum magis et magis introsus aspexi singulaque notavi, manifestaverunt se vulpes parvulae quae demoliuntur vineas, maxime dum vinea floruit.” Palémon Glorieux, ed., Jean Gerson. CEuvres complètes, vol. 2 (Paris 1960-1973) 259-260; henceforth: Glorieux, vol. and page number.

2 “Tu autem, homo Dei, hos devita. Recipe igitur, frater carissime missum qui tibi revertitur librum Hubertini cum cautela legendum vel omnino negligendum." Glorieux, 2.263. 
"simple", lay people or monks judged incapable of identifying for themselves the truth of faith among deceitful doctrinal subtleties ${ }^{3}$.

The same pastoral concern leads Gerson to revisit Ubertino's work on 18 September of the following year, this time articulating his critique in the form of a letter-treatise on the Incarnation, De susceptione bumanitatis Christi ${ }^{4}$. We find ourselves again in the Celestine convent in Lyon: the letter is addressed to their provincial, Jean Bassandi, who, like his fellow brother, had asked the ex-chancellor's expert counsel on certain points of doctrine contained in the Arbor vitae ${ }^{5}$. With this letter, Gerson intends to correct the "inexperienced zeal” which inhabits the spirit of "the simple religious ignorant of theology". Their lack of discernment "leads them to consider evangelical any book dealing with the Gospels"6. Gerson proposes to guide them towards a cautious reading of the work in question, on the basis of a small treatise explaining the content of faith in simple fashion, suitable for the instruction of the non-initiated ${ }^{7}$.

Gerson's letters to the Celestines have retained the attention of the specialists on two counts: as an expression of the evolution of Gerson's understanding of the mystical union - this is notably the case for the 1425 letter - and as witness to the censure mechanisms of the ecclesiastical hierarchy. Regarding the first letter, let us simply recall that André Combes saw in these passages a "conversion" within

3 "Sufficerit igitur ad praesens commonuisse lectorem praedicti Humbertini sicut et aliorum extranea tradentium sub specie subtilitatis vel excellentis traditionis, quod omnia regulent et examinent juxta veritatem evangelicam et doctores communiter approbatos, alioquin noverint se periculis maximis errorum et haeresum proximos esse." Glorieux, 2.261. See Daniel Hobbins, Gerson on Lay Devotion, dans A Companion to Jean Gerson, ed. Brian P. McGuire (Leiden, Boston 2006) 41-78; henceforth: Hobbins, Lay Devotion.

4 This is one of the most popular letters within Gerson's vast epistolary collection: we dispose with more than 30 extant manuscripts. See Hobbins, Lay Devotion 62.

5 Thus the incipit of the letter: "Reverendo patri domino provinciali Coelestinorum, fratri Joanni Bassandi, suus Joannes cancellarius Parisiensis, ea quae ad pietatem sunt christianae religionis et sursum actionis jugiter meditari ... De qua susceptione colligamus aliquas veritates accommodas petitioni tuae, pater honorande." Also: "Subjugantur aliae duodecim veritatis propinquius ad interrogationem tuam, pater amantissime, terminos non deserendo susceptos." Finally: "Haec habuimus, pater religiosissime simul et prudentia praestantissime, quae currente calamo linguam animi ferventis exprimente volui satisfaciens tuque petitioni notare per cedulam istam." Glorieux, 2.264, 2.269 and 2.274 respectively.

6 " $[\mathrm{N}]$ on rememoramur ista detractionis malignantis zelo, quantum conscientia testis est, sed cautelae prudentis et commonentis studio quatenus religiosi simplices et inscii theologiae, nec habentes spiritum discretionis spirituum, in devotis apparentibus sentimentis falli valeant in lectura vel studio sub fervore novitio, sub indiscreto judicio, quod liber totus sit evangelicos quia de evangelico loquitur." Glorieux, 2.274.

7 In his sermon Bonus pastor (Glorieux, 5.127 and 132), Gerson encourages the publication of treatises "in quibus generalis tenor nostre fidei et preceptorum et sacramentorum cum similibus contineatur, quatenus in eis sacerdotes et curati simpliciores legere possint et instrui quid ipsi scire, quid alios docere debeant". See also the sermon De vita clericorum (Glorieux, 5.452) and De duplici statu in Ecclesia (Glorieux, 9.31). In this respect, see Geneviève Hasen$o h r$, La société ecclésiale selon le chancelier Gerson, in: Pfaffen und Laien - ein mittelalterlichen Antagonismus? Freiburger Colloquium (1996), ed. E. Conrad et E. Tremp. (Scrinium Friburgense 10, Freiburg Schweiz 1999) 225; henceforth: Hasenohr, La société ecclésiale. 
Gerson's mystical theology, whereby the ex-chancellor would have understood the mystical union no longer as a union of love brought about by the operation of a specific faculty, but as a union of essence to essence performed at the level of sanctifying grace ${ }^{8}$. On the other hand, Gerson's letters could indeed be assimilated to a kind of censure, insofar as they aspire to guide their addressees towards a revised and corrected reading of Ubertino's work ${ }^{9}$. In this perspective, historians have attempted to identify the concrete, and mostly negative, effects of Gerson's influence on the reception of certain mystical authors. Marie Robinne, a female visionary favoured by the Celestines, sinks into oblivion little after her death in 1399. According to Hélène Millet, Gerson's correspondence with the Order, just as his treatises on the discernment of spirits, would have contributed to the disappearance of that channel of diffusion of her prophecies ${ }^{10}$. Similarly, André Vauchez attributed the unpopularity of Bridget of Sweden in France to the hostility of the great doctors, in particular Henry of Langenstein and Gerson. Their general distrust towards the proliferation of false revelations was strongly encouraged by the "Roman" sensibility of the visionary before the Schism and by her support of the English cause during the Hundred Years War"1.

Focusing on the 1426 letter, in what follows I would like to shed new light on the nature and motives of the correspondence between Gerson and the Celestines. Far from the binary pattern portraying the theologian as exclusive holder of doctrinal authority and thereby entitled to impose his model of truth to the non-initiated, this article attempts to bring to the fore the normative plurality at work in Gerson's epistolary exchange. Indeed, our letter contains a debate on the Incarnation and on religious perfection held between a theologian who is both sensitive to mystical theology and keen on conveying the orthodox doctrine to the noninitiated; a monk whose membership to an Order open to the influence of mysti-

8 André Combes, La théologie mystique de Gerson. Profil de son évolution, vol. 2 (Rome 1965) 465-568; henceforth: Combes, La théologie mystique. In this respect, see also Marc Vial, Jean Gerson. Théoricien de la théologie mystique (Paris 2006) esp. 148-164; henceforth: Vial, Jean Gerson.

9 Those "limitations à l'usage didactique" (Bianchi) were notably applied in the $13^{\text {th }}$ century to Aristotle's libri naturales by the ecclesiastical authorities. See Luca Bianchi, Censure et liberté intellectuelle à l'Université de Paris (XIIIe-XIVe siècles) (Paris 1999) 27-29.

10 See Hélène Millet, Ecoute et usage des prophéties par les prélats pendant le Grand Schisme, in: Les textes prophétiques et la prophétie en Occident (XIIe-XVIe s), Colloque de Chantilly (30-31 mai 1988), ed. A. Vauchez, MEFRM 102 (Rome 1990) 441, 454: "L'absence de diffusion du texte écrit de ses révélations me paraît imputable à l'influence qu'exerça Gerson sur ses procurateurs, les Célestins." Henceforth: Millet, Ecoute et usage.

11 André Vauchez, Saints, prophètes et visionnaires (Paris 1999) 163-206; henceforth Vauchez, Saints, prophètes. On the other hand, the cautious but rather positive judgement that Gerson emits on the Vita of Ermine of Rheims in 1401 probably exercised a favourable influence on the textual tradition of her visions. In this respect, see Wendy Love Anderson, Gerson's Stance on Women, dans A Companion to Jean Gerson, ed. Brian P. McGuire (Leiden, Boston 2006) 296-297; henceforth: Anderson, Gerson's Stance on Women; also C. Arnaud-Gillet, Entre Dieu et Satan: les visions d'Ermine de Reims (1396) recueillies et transcrites par Jean le Graveur (Florence 1997). 
cal authors does not prevent him from appealing to the master's expert counsel; and a spiritual Franciscan whose model of truth and alternative value system purport to have an authority in their own right. The issue at hand is thus threefold. First of all, at the doctrinal level: can the theologian's competence justify the imposition of a model of truth to all believers? Secondly, can fidelity to the Gospels and the claim of charismatic gifts guarantee the legitimacy of an alternative ideal of religious perfection? Finally, at the pastoral level: how to encourage devotion without falling into error and compromising Christian truth ${ }^{12}$ ? Indeed, the question of theological authority gains in complexity as we realise that Gerson's attitude towards the spirituality of his time is not univocal. As we shall see, our author places himself both at the summit of an intellectual hierarchy in which the theologian is alone capable of creating norms ${ }^{13}$, and in the margins of all recognised hierarchy as he shares with the non-initiated the conviction that spiritual richness is gained through the simplicity of the soul rather than by rational subtleties. As I hope to be able to show, this dichotomy betrays a whole new conception of the theologian's responsibility, grounded not on a one-way normative model, but on a pastoral concern which I believe closer, to the humanists' moral preoccupations than to scholastic speculative thought.

In what follows, I shall first deal with the gersonian understanding of theological authority in respect to other forms of doctrinal power. Secondly, some remarks will be made concerning the addressee of our letter and the spiritual tradition to which he belongs. I shall then consider the content of the letter, that is, Gerson's examination of certain points of doctrine treated in the Arbor vitae. Following Gerson's lead, our study will appeal when relevant to the criteria developed in $D e$ examinatione doctrinarum, an earlier work (1423) devoted to the question of the discernment of spirits ${ }^{14}$. To conclude, a brief comment will be made regarding the significance of the model of theological authority proposed by Gerson.

12 On this last question, see Hobbins, Lay Devotion 42-44.

13 On this topic, see Hasenohr, La société ecclésiale 209-233.

14 "Simul hoc interim scripsimus conformiter ad tractatulum illum qui De examinatione doctrinarum compositus est." Glorieux, 2.274. For a recent edition of the De examinatione, see Xavier Loppinet, Le De examinatione doctrinarum de Jean Gerson (1363-1429) et la réception universitaire des auteurs mystiques à la fin du Moyen age. Tome I: Introduction, Status quaestionis, Histoire du texte, texte et traduction; Tome II: Commentaire, Conclusion, Annexes, Bibliographie et Index. Doctoral thesis submitted to the Catholic Theology Faculty, Université Marc Bloch (Strasbourg 2005); henceforth: Loppinet, Le De examinatione, vol. and page number. I am very grateful to François Boespflug for having provided me with a sample of the thesis he supervised. In order to facilitate the reference, I will cite P. Glorieux's more current edition of the De examinatione: CEuvres complètes (Paris 19601973) 9.458-475. Let it be said in passing that Gerson wrote two other works on the discenment of spirits: the De probatione spiritum of 1415 (Glorieux, 9.177-185) and the De distinctione verarum visionum a falsis of 1401 (Glorieux, 3.36-56). On this subject, see B. J. Craiger, Doctrine and Discipline in the Church of Jean Gerson, in: Journal of Ecclesiastical History 41.3 (1990) 389-407; henceforth: Craiger, Doctrine and Discipline. See also François Vandenbroucke, Discernement des esprits, in Dictionnaire de Spiritualité 3 (Paris 1957) col. 12631264. 


\section{The theologian's authority: Gerson and the Pauline ideal}

Gerson's understanding of theological authority belongs to the broader context of his ecclesiology ${ }^{15}$. Placed between papal authority, purely juridical, and that of simple lay educated persons, the theologian's authority is hybrid: his power to judge derives both from the licentia docendi he has received from the apostolic authority and from his doctrinal expertise. On this question, the De examinatione refers to the emblematic correction made to Peter by Paul in Gal. 2, 11-14. On Gerson's reading, doctrinal knowledge was transmitted to theologians by Paul, so that beside the hierarchical succession symbolised by Peter, there is a specifically doctrinal succession symbolised by Paul. As successor of Paul, the theologian has the right and the responsibility to correct the pope, not only on doctrinal matters, but also in any other circumstance in which the unity of the Church would be compromised ${ }^{16}$.

As doctrinal arbiter, the theologian also has the duty of interpreting and confirming revelations ${ }^{17}$. The master's authority lies as much in his knowledge as in his capacity to formulate a judicious opinion on particular cases. In technical terms, Gerson is here referring to epikie ${ }^{18}$, generally translated as "fairness". Of Aristotelian origin ${ }^{19}$, epikie denoted a certain benevolence or goodwill on the part of the legislator in the interpretation of the law, where a strict adherence to the letter would cause harm to the common good. Key of the art of discernment, epikie is often assimilated by Gerson to discretio or the power to distinguish between true and false doctrines ${ }^{20}$. Whenever he resorts to the term, epikie implies an insufficiency in the positive law and calls for a "spiritual" interpretation" ${ }^{21}$. The pronuncement of a judicious opinion on these matters pertains primarily to the theology master by reason of its doctrinal training. Indeed, far from the canonists' legal rigorism, theologians enjoy a privileged knowledge of the divine law which allows

15 There is a vast literature on this subject. Let us simply cite the following: G. H. M. Postbumus Meyjes, Jean Gerson. Apostle of Unity. His Church Politics and Ecclesiology, trans. J. C. Grayson (Leiden, Boston 1999); henceforth: Meyjes, Jean Gerson; Louis B. Pascoe, Jean Gerson. Principles of Church Reform (Leiden 1973); henceforth: Pascoe, Jean Gerson; B. J. Craiger, Doctrine and Discipline; Steven E. Ozment, The University and the Church Patterns of Reform in Jean Gerson (Mediaevalia et Humanistica. Studies in Medieval and Renaissance Culture 1, ed. P. M. Clogan (Cleveland, London 1970) 111-126; henceforth: Ozment, The University; Francis Oakley, Gerson as Conciliarist, in: A Companion to Jean Gerson, ed. Brian P. McGuire (Leiden, Boston 2006) 179-204; henceforth: Oakley, Gerson. 16 See Glorieux, 9.460-461. For other instances of the Pauline passage in Gerson's work: Nimis honorati sunt (Glorieux, 7.2.722) and An liceat (Glorieux, 6.284). See also Meyjes, Jean Gerson 331-336; Craiger, Doctrine and Discipline 400-402; Pascoe, Jean Gerson 90-92.

17 Glorieux, 9.463. See also Loppinet, Le De Examinatione, II. 237-238.

18 J. Godefroy, Epikie, in: Dictionnaire de théologie catholique 5.1 (Paris 1913) col. 358-361.

19 Ethique à Nicomaque, V.10, 3.

20 See for example the sermon Pax vobis (Glorieux, 5.441 and 443); De potestate ecclesiae (Glorieux, 6.230); De vita spirituali animae (Glorieux, 3.189); Conversi estis (Glorieux, 7.177); De unitate ecclesiae (Glorieux, 6.138 and 142).

21 See Meyjes, Jean Gerson 241-246. 
them to judge according to Christ's (the legislator's) intention towards the edification of the Church 22 .

The model of theological authority outlined in Contra curiositatem studentium completes the portrayal proposed by Gerson. Addressed in 1402 to Paris University theologians, this double lecture develops the harmful effects that a curious spirit and the search for singularity (singularitas) have on university theology. Articulated around a commentary on Mark 1, 15 ("Let your hearts be turned from sin and have faith in the Gospel”), Gerson encourages a theological reflection led by the promotion of faith and charity, against the tendency, in his view typically scholastic, to privilege a school of thought at the expense of any attempt to harmonise the teaching of the Church. In a spirit of humility and not of intellectual pride, the theologian is called forth to safeguard union in charity and not sectarian division ${ }^{23}$. Once again, it is the Pauline model of the edifying force of charity that underlies Gerson's thought ${ }^{24}$.

The equivocal relationship that Gerson held with the spirituality of his time comes to the fore. On the one hand, he appears as the spokesman of university theology and the hierarchical Church as he condemns the proliferation of private revelations by simple lay people; on the other hand, he shares with contemporary spiritual authors the idea that mystical contemplation and charismatic gifts are not the prerogative of the clergy, since it is not by science but by humility and grace that one can access such a state ${ }^{25}$. Gerson's ambivalent attitude could explain the

22 Gerson is not the first to accuse the canonists of legal positivism. He takes on an old theme that Ockham (Dialogus, I.1, 1-15), among others, had already discussed. Like Ockham, Gerson maintains that the determination of the truth of faith, just as the judgement of heresy, fall within the theologian's responsibility on the grounds of his "superior science", to which canon law remains subordinated. See also Albert the Great, Sent., IV d. 27, 21; Thomas Aquinas, Summa theologica IIaIIae q. 88 a. 11 and Quodl., XI q. 8 a. 8; Roger Bacon, Opus tertium (ed. Brewer) 85-86. On this subject, see Meyjes, Jean Gerson 210-246; Ozment, The University 117-119; Pascoe, Jean Gerson 74-89; Mark Borrows, Jean Gerson and the De Consolatione theologiae (1418). The Consolation of a Biblical and Reforming Theology for a Disordered Age (Tübingen 1991) 126-135.

23 Glorieux, 3.238 and 242: "Placuit hujus doctoris inter caeteros meminisse dum haec loquor magis monitione doctrinali quam subtili inquisitione, quoniam ipse doctor non singularitate contentiosa vincendi, sed humilitate concordandi uti mihi visus est." In this respect, see also the sermon Ad Deum vadit (1403): Glorieux, 5.7. See also Ozment, The University 112-114; Marc Vial, La curiosité, anti-modèle de la théologie: Calvin et Gerson, in: Bulletin de la Société de l'histoire du protestantisme français 155 (2009) 29-40, esp. 35-40. A. Combes sees in Gerson's double lecture "à la fois le programme et le premier acte de la réforme [de l'enseignement] gersonienne": La théologie mystique de Gerson, profil de son évolution, vol. 1 (Rome 1963) 31.

24 See for example I Co 8, 1: "Knowledge gives pride, but charity gives true strength." On this topic, see also Ch. Burger, Aedificatio, Fructus, Utilitas. Johannes Gerson als Professor der Theologie und Kanzler der Universität Paris (Beiträge zur historischen Theologie 70) (Tübingen 1986) 35-40.

25 I am paraphrasing here Geneviève Hasenohr, Aperçu de la diffusion et la réception de la littérature de spiritualité en langue française au dernier siècle du Moyen age, in: Wissensorganisierende und wissensvermittelnde Literatur im Mittelalter. Perspektiven ihrer Erforschung. Kolloquium 5.-7. Dezember 1985, ed. N. R. Wolf (Wiesbaden 1987) 68, 79: “la con- 
admiration he reserved to Bonaventure, scholastic theologian of great mystical sensibility. Indeed, Gerson will not hesitate to recommend the reading of Bonaventure's works in his correspondence with the Celestines. Both his brother Jean and Bassandi are encouraged to revisit the work of the Franciscan, as a way to stimulate spiritual life while restraining its domain of application to doctrinally safe authors ${ }^{26}$.

\section{The pious ears: Bassandi and the Celestines}

The copious correspondence that Gerson kept with the Celestines and the Carthusians during his exile in Lyon constitutes a rich corpus of the gersonian ideal of the religious life. In these letters, mostly devoted to questions of religious, discipline and cases of conscience, Gerson guards his readers against the manifestation of immoderate scruples and the adoption of unusual behaviour. Loyal to the Pauline ideal of the theologian who acts judiciously for the edification of the Church, Gerson encourages his correspondents to conform as much as possible to common practice, advising them to abstain from all behaviour which could trouble the simple souls ${ }^{27}$. The avoidance of scandalum pussillorum is a constant concern in Gerson's letters, and the letter to Jean Bassandi is no exception ${ }^{28}$.

First prior of the Celestine monastery in Amiens before assuming his charge in Lyon, Bassandi (c. 1360-1445) had once been the confessor of Colette of Corbie ${ }^{29}$. This biographical detail is not lacking in importance. Initially a member of the beguine community in Corbie, saint Colette (1381-1447) is better known as a rigor-

templation n'est pas l'apanage des clercs, puisque ce n'est pas par la science, génératrice d'orgueil, qu'on y parvient, mais par l'humilité et la grace”. Henceforth: Hasenohr, Aperçu.

26 Gerson's admiration for Bonaventure is well known. The Franciscan theologian is recurrently cited by the ex-chancellor, both as a salutary corrective and a spiritual ideal. On this topic, see Palémon Glorieux, Gerson et saint Bonaventure, dans S. Bonaventura. 1274-1974 (Roma 1974) 773-791; Sven Grosse, Johannes Gerson und Bonaventura: Kontinuität und Diskontinuität zwischen Hoch- und Spätmittelalter, in: "Herbst des Mittelalters?" Fragen zur Bewertung des 14. und 15. Jahrhunderts (Miscellanea Mediaevalia 31), ed. Jan A. Aertsen et Martin Pickavé (Berlin, New York 2004) 340-348. The commendation of Bonaventure's work also closes the treatise De examinatione doctrinarum: Glorieux, 9.475. See also Gerson's letter to a friar minor, where he encourages a return to the old Franciscan tradition represented by Bonaventure and Alexander of Hales: Glorieux, 2.276-280.

27 On this subject, see Gilbert Ouy, Gerson and the Celestines. How Jean Gerson and his friend Pierre Poquet replied to various questions of discipline and points of conscience (ca. 1400), in: Reform and Renewal in the Middle Ages and the Renaissance. Studies in honor of L. Pascoe, ed. M. Izbicki et C. M. Bellito (Leiden 2000) 113-140; Palémon Glorieux, Gerson et les Chartreux, in: Recherches de théologie ancienne et médiévale 28 (1961) 115-153. In his insistence on moderation and sobriety, Gerson shows remarkable similarities with the stoic tradition, in particular Seneca. For the latter, see Letters to Lucilius, 5.

28 See for example the $8^{\text {th }}$ and $9^{\text {th }}$ truths of our letter: Glorieux, 2.271.

29 For a biographical note, see B. Heurtebize, Bassand (Bienheureux Jean), in: Dictionnaire d'histoire et de géographie ecclésiastiques 6 (Paris 1932) col. 1263-1264. 
ist Clarisse involved in the reform movement of the Franciscan Order. But the life and work of Colette transcend the purely institutional context to see her intervene within the context of political unrest of her time. Numerous revelations would have thus encouraged her to work for the end of the Schism next to the Aragonese Dominican Vincent Ferrer ${ }^{30}$. Now, we know the mistrust Gerson reserved to female visionaries and their confessors. In the De examinatione, he suggests that an effective remedy for avoiding deceptive fantasies regarding charismatic gifts is to consider the visions with humility - humility being in Gerson's view a sign of true grace - by submitting oneself to the experts' advise and fleeing the flattery of ill-advised spiritual directors ${ }^{31}$. Gerson's treatment of this issue forms part of his more general concern for the spiritual counsel of simple believers and the edification of the Church. He is keen on correcting certain attitudes that he associates with the recent Schism: hasty judgements, lacking in discernment and formulated in a spirit of vanity rather than humility were also behind the cult to Bridget of Sweden and the credit given to Jan Hus's ideas.

At first sight, Bassandi's background could hardly comfort Gerson's qualms. Belonging to an Order whose origins went back to Celestine V, a pope of contested authority known for his feats of austerity and the protection offered to the spiritual Franciscans $s^{32}$, Bassandi would have in addition been associated with the new spirituality as confessor of a visionary and rigorist Clarisse. Indeed, as the works of Hélène Millet and Geneviève Hasenohr admirably show, the Carthusians and the Celestines were the propagators par excellence of the works of mystical authors, at a time when the instability of the ordinary ecclesiastical authorities had opened the way for the non-initiated to serve as intermediaries of the Spirit $^{33}$. Amongst a more traditional literature including saint Bernard, the Victorines and Bonaventure, the Carthusian and Celestine libraries also held samples of the work of Catherine of Sienna, Angela of Foligno's "Book", Marguerite Porette's "Mirror" and Ermine of Rheims's "Visions" 34 . And yet, symptomatic of the place Gerson occupied in the spiritual landscape of his time, the same shelves included his own works on spirituality. Treatises such as the Montagne de la con-

30 See Elizabeth López, Culture et sainteté. Colette de Corbie (1381-1447) (Publications de l'Université de Saint-Etienne 1994); Pierre de Vaux, Vie de sœur Colette (Publications de l'Université de Saint-Etienne 1994).

31 For the De examinatione: Glorieux, 9.469. For the De probatione: Glorieux, 9.184. See also Anderson, Gerson's Stance on Women 305-307. In their intention to impart spiritual counsel, treatises on the discernment of spirits constitute in Anderson's view a genre analogous to confessors' manuals.

32 For Celestine V, see Peter Herde, ed., Die ältesten Viten Papst Cölestins V. (Peters vom Morrone) (Scriptores rerum Germanicarum, Nova series 23, Hannover 2008); Id., Cölestin V. (1294), Peter vom Morrone. Der Engelpapst. Mit einem Urkundenanhang und Edition zweier Viten (Päpste und Papsttum 16, Stuttgart 1981).

33 Millet, Ecoute et usage 425-455. See also Studies in Carthusian monasticism in the late Middle Ages, ed. Julian M. Luxford (Brepols 2008).

34 Hasenohr, Aperçu 78-79; Millet, Ecoute et usage 441. See also Loppinet, Le De examinatione II.129-160. 
templation, the A.B.C. des simples gens and the Mendicité spirituelle were all written in the vernacular for pastoral purposes, in order to encourage the contemplative life of lay people or monks within the boundaries of doctrinally safe teaching ${ }^{35}$. It is in this perspective that Gerson intends to guide Bassandi in his reading of the Arbor vitae.

\section{The fox and the vines: Ubertino and the theological tradition}

A prolix and multilayered work of eschatological content, Ubertino de Casale's Arbor vitae could not escape Gerson's critical evaluation. At its most basic level, we find a life of Christ in two prologues and five books, composed around the image of the tree following the model established by Bonaventure's Lignum vitae. At another level, Ubertino's work purports to give an account not only of Christ's life on earth, but also of the totality of the history of salvation from Creation to the end of the world, passing through Christ's Second Coming ${ }^{36}$. In a monograph devoted to the Arbor vitae, Carlos Martínez Ruíz describes the work in terms of a theological summa: indeed, Ubertino intends to offer an explanation of the essentials of Christian doctrine in a language which escapes the formal constraints proper to scholasticism, but which betrays the same concern to exhibit the totality of theological knowledge in organic fashion ${ }^{37}$. From another perspective, the $A r$ bor vitae consists in a devotional meditation on Christ's life and Passion, whose ultimate aim is mystical union and the profound transformation of the individual practising it. It is possibly on this count that the Celestines came across it and became interested in Ubertino's work. We know that meditated "Passions" and "Lives of Christ" occupied a central place in $15^{\text {th }}$-century spirituality and filled the shelves of monastic libraries ${ }^{38}$. Ubertino's Arbor vitae could have thus been easily assimilated to a literary corpus of devotional use intended to encourage personal piety and reflexion ${ }^{39}$.

Several points of doctrine developed in the Arbor vitae capture Gerson's critical attention. He condemns, as he did in the 1425 letter, Ubertino's interpretation of the Biblical passage Nunc dimittis, in which the old Simeon prophesises on Jesus's

35 Hasenohr, Aperçu 67-69, 80.

36 See Carlos M. Martínez Ruíz, De la dramatización de los acontecimientos de la Pascua a la cristología. El cuarto libro del Arbor vitae crucifixae Iesu de Ubertino de Casale (Rome 2000) esp. 114-117; henceforth Martínez Ruíz, De la dramatización. On Ubertino, see Gian Luca Potestà, Ubertin de Casale, in: Dictionnaire de spiritualité 16 (Paris 1994) col. 3-15.

37 Martinez Ruíz, De la dramatización 94-114.

38 Hasenohr, Aperçu 80-81.

39 As Stephen Mossman's recent study shows, the Arbor vitae constituted a text of devotional use popular in the $15^{\text {th }}$ and $16^{\text {th }}$ centuries, particularly in the circles of the Brethren of the Common Life in Flemish and Germanic regions. See Stephen Mossman, Ubertino da Casale and the Devotio moderna, forthcoming in Ons Geestelijk Erf 80 (2009) 199-280; henceforth: Mossman, Ubertino da Casale. I wish to thank the author for having facilitated a copy of his article before publication. 
mission and announces to Mary the suffering she will undergo. Locus classicus of the theology of history of joachimite inspiration, Simeon's canticle is believed to foreshadow the withdrawal of the clerical hierarchy opening the way to a new order, the ordo contemplantium, leading actors of the age of the Spirit and to whom the spiritual Franciscans became rapidly identified ${ }^{40}$. Beyond its eschatological dimension, in his view questionable and dangerous, Gerson warns his interlocutor against the moral rigorism propounded by this model of religious perfection ${ }^{41}$.

But the main body of the letter to Bassandi is occupied with another topic, amply developed in the Arbor vitae: the suffering of Christ and his mother and the model of spiritual perfection they inspire. The Mariological theme offers the leading thread. Gerson's criticism against Ubertino is articulated around a commentary on the penultimate verse of the Magnificat: "He has helped his servant Israel"

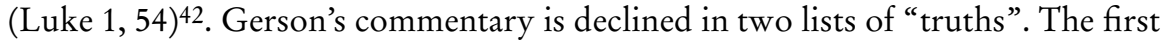
list of twenty-four truths is based on a typological interpretation of Luke's verse. The help offered by God to his people signifies in this sense the redeeming value of Christ's Passion, the subject developed in this part of Gerson's treatise. A second list of twelve truths constitutes an analogical interpretation of the Biblical verse, according to which the help offered by God represents the grace that man receives towards a perfect union with God ${ }^{43}$. This prepares the terrain for a discussion on the model of perfection contained in the Arbor vitae. The discourse's arrangement in lists of "truths" constitutes a significant stylistic feature. As Daniel Hobbins has recently noted ${ }^{44}$, this way of organising the text, recurring in Ger-

40 See Ubertino de Casale, Arbor vitae crucifixae Iesu (Venise 1485) book II, chapter 5, esp. f. 113b-115b; henceforth: Arbor vitae, book and chapter number. For Joachim of Fiore's interpretation of Simeon's canticle, see Gian Luca Potestà, Joachim de Flore dans la recherche actuelle, in: Oliviana 2006. http://oliviana.revues.org/document39.html. Id., Il tempo dell'Apocalisse. Vita di Gioacchimo da Fiore (Roma, Bari 2004). For Ubertino's eschatological doctrine, see Id., Storia ed escatologia in Ubertino da Casale (Milano 1980).

41 Glorieux, 2.273.

42 As Gerson himself tells us towards the end of his letter, he composed his treatise following the commentary on one of the verses of the Magnificat that he was composing on the same day: Glorieux, 2.274. Completed probably in 1428, the Collectorium super Magnificat consists in a collection of twelve treatises, each devoted to the commentary of one verse of Mary's canticle. For a more detailed study on the structure of the Collectorium, see Isabelle Fabre, La doctrine du Chant du Cœur de Jean Gerson. Édition critique, traduction et commentaire du Tractatus de canticis et du Canticordum au pèlerin (Genève 2005) 187-194.

43 Gerson's considerations in this section are remarkably similar to some notes he had included in a "supplement" to De examinatione, in which he deals with the "three remaining modes" to treat in the examination of doctrines. See Glorieux, 9.473-475. A note by Gerson's brother, Jean the Celestine, adds value to this testimony. The latter explains to the reader that the treatise has not been and will not be completed. Taking into account what Jean the Celestine tells us on this matter, one wonders if this section of the letter constitutes a later attempt to tackle the third part, never initiated, on the practical norms to be followed for the judgement of "particularum sentimentorum circa diversas scripturae particulas". Loppinet, Le De Examinatione I.94.

44 Daniel Hobbins, The Schoolman as Public Intellectual: Jean Gerson and the Late Medi- 
son, is symptomatic of an evolution in the practice of theology. Far from university doctrinal disputations, the study of concrete cases in the form of "tracts" allows Gerson to articulate his thought in a concise and uncomplicated manner 45 . More importantly, this new way of laying out theological reflection responds to the author's intention of rendering his work accessible to the non-initiated and suitable for a wider circulation. The image of the theologian is thereby transformed to become assimilated to that of the "physician" applying his judgement to particular cases on the basis of his experience. Like a spiritual counsellor, Gerson's ideal theologian is keen on establishing a dialogue with "simple" lay people in order to guide them towards a sober and safe form of piety ${ }^{46}$.

On the other hand, the term of "truth" chosen by Gerson to punctuate his reflection betrays a normative intention which takes us back to a previous work ${ }^{47}$, in which Gerson establishes six degrees (gradus) of truth requiring a decreasing order of adherence. The first three degrees define orthodox doctrine: the Scriptures, the apostolic tradition and the revelations made to certain individuals and confirmed by the Scriptures or by the Church. These superior degrees of truth, directly revealed by God, constitute the articles of faith, necessary for salvation. The inferior set of truths derives logically from the first three and are only probable: so for example, that Christ was made of flesh and bones can be deduced from the Scriptural teaching that he was a man. The sixth and last degree corresponds to truths that "nourish or promote piety and religious devotion"48: the legends and miracles of saints, the life of the Fathers, the opinions of the doctors of the Church, and more to our purposes, the visions of devout persons, are all expressions of "pious truths" authorised by the Church. If the doctrine in question is uncertain, the spirit of epikie advises to doubt piously rather than to determine hastily ${ }^{49}$. Indeed, to oppose oneself to this kind of devotion would "be unadvis-

eval Tract, in: American Historical Review 108 (2003) 1308-1335; henceforth, Hobbins, The Schoolman.

45 In this respect, see Gerson, Contra curiositatem studentium: Glorieux, 3.247.

46 See for example the "supplement" to De examinatione: "In examinatione doctrinarum consulendi sunt experti circa particulares casus et eventus, quos suis temporibus invenerunt. Primo, quia certius secundum Aristotelem judicat experientia quam ars, et expertus quam artifex. Secundo, quia non sicut actiones humanae circa generalia sed individuis, sicut medicus non sanat hominem, sed hunc hominem; ita moraliter agens non dicitur facere opus in genere, sed hoc opus in singulari, scilicet cum circumstantiis debitis omnibus, istis et illis. Tertio, quia prudentia quae doctrix est operum humanorum, praesuponit experientiam tam ex praeteritis quam ex praesentibus, ex quibus futura conjecturat." Glorieux, 9.473-474. See also Hobbins, The Schoolman 1334-1335.

47 Declaratio compendiosa quae veritates sint de necessitate salutis credendae, probably from 1416: Glorieux, 6.181-189.

48 Glorieux, 2.269: "[24a veritas]: [propositiones de pietate fidei sunt] omnes illae scilicet quae nec evidenter sequuntur ex contentis in sacra Scriptura, nec etiam patenter repugnant, et aedificant caritatem vel devotionem pii cordis temerarie nihil asserentis”. See also De puella Aurelianensi (1429): Glorieux, 9.659-662.

49 Glorieux, 6.184-185. In this respect, see also Hobbins, Gerson on Lay Devotion 47-48. 
able and uncharitable"50. According to this hierarchy, Ubertino's Christological doctrine would correspond to truths necessary to faith, whereas his model of religious perfection would qualify as "truths of piety", thus raising the question of the discernment of spirits.

Let us now examine each list of truths separately. The first contains two rather controversial topics of the fourth book of the Arbor vitae: the suffering of Christ (truths 1-8, 13 and 14) and Mary's sorrows and the privileges granted by her Son (truths 9 to 23). Derived from Peter John Olivi's theology, the doctrine of the interior suffering of Christ, described here in terms of dolores cordiales ${ }^{51}$, conveys Ubertino's understanding of spiritual perfection in the imitation of Jesus's life ${ }^{52}$. Chapter 9 contains the relevant passage. It concerns Christ's prayer in the garden of Gethsemane, prior to his crucifixion. The Biblical verse in Mat. 26, 37-38, according to which Christ's soul became "very sad, even to death", sets the grounds for a discussion on the nature of Christ's emotions before his death. The exegetical tradition had viewed Christ's sorrows at Gethsemane as an emotion preceding the passion (propassio): a manifestation of his natural will which, contrary to his rational will respectful of God's superior design, did not want to undergo suffering. ${ }^{53}$ Ubertino sets himself apart from this tradition. The sorrow which Christ manifested at Gethsemane was not a temporary expression of his human will ${ }^{54}$. According to Ubertino, Christ would have suffered such affliction from the moment of his conception in Mary's womb, thus foreshadowing the pain he was to undergo in his physical and mystical body (the elect $)^{55}$. Moreover, Christ's sorrow

50 See Glorieux, 2.94, letter from 1401, in which Gerson considers the visions of Ermine de Reims.

51 The importance of these topics in the doctrine of the Arbor vitae, as well as its Olivian inspiration, are pointed out in the Prologue: "Qui [Olivi] me modico tempore, spiritu Iesu preveniente, sic introduxit ad altas perfectiones anime dilecti Iesu et sue dilectissime matris, et ad profunda scripture, et ad intima tertii status mundi, et renovationis vite Christi; ut iam ex tunc in novum hominem mente transiverim." Arbor vitae, Prol. 1, 4b. We know that Ubertino had had the opportunity of meeting Olivi during his stay at the convent of Santa Croce in Florence (1285-1289), when Olivi occupied the position of lector. The influence that Olivi exercised on Ubertino is attested in several passages of the Arbor vitae. On this subject, see Martínez Ruiz, De la dramatización 171-177.

52 See Martínez Ruíz, De la dramatización 114-117.

53 For the discussion on the traditional interpretation of the Biblical passage, see Kevin Madigan, The Passions of Christ in High-Medieval Thought. An Essay on Christological Development (Oxford 2007) 63-71; also Simo Knuuttila, Emotion in Ancient and Medieval Philosophy (Oxford 2004) 193-195. See also Mossman, Ubertino da Casale.

54 "Licet autem mens Christi fuerit in continuo apice summitatis omnium virtutum, et nunquam mutabiles virtutes variantes mentem eius intraverunt ... Conveniens tamen fuit, quod id quod latuit intra sue perfectionis secretum ab utero matris sue ipse signis sensibilibus suis fidelibus revelaret; quidem maxime imminente mortis transitu decens fuit. Et sicut ille sudor sanguineus est signum omnem humanam superans rationem, ita agonia dolorem cordis Iesu, que illo figurabatur sudore, comprehensionem omnis superat creature." Arbor vitae, IV.9, 307b-308a.

55 "Hoc signum sudoris partim fuit memorativum omnium dolorum, quos ab instanti conceptionis sue in corpore occultavit; partim representativum illorum, quos in pressenti agonia 
is caused by the knowledge he had of all human sin, past, present and future. Ubertino thus goes well beyond the traditional understanding of Christ's sacrifice and the remission of human sin. Christ is here personally and directly affected in his spirit by the totality of man's sins, including those we commit after his death and Resurrection. ${ }^{56}$ The redeeming value of the Passion thus lies in the continuous affliction underwent by Christ's heart, equivalent to the total accumulation of human $\sin ^{57}$.

Gerson concedes that according to faith Christ's blessed soul enjoyed perfect knowledge of the merits and faults of each man ( $2^{\text {nd }}$ truth). On the other hand, the Scriptures cannot confirm the doctrine that Christ suffered pain as a direct result of his knowledge of human $\sin \left(3^{\text {rd }} \text { truth }\right)^{58}$. He certainly experienced a strong aversion against man's sins, but this should be understood in a "broad and figurative" sense (largo et tropico modo loquendi), as signifying a "distaste in the heart" (displicentia cordis) or, in a "more extensive transposition" (extensiori transsumptione), as "grief or sadness" (4th truth). In its essence, the content of Ubertino's Christology is not false; what renders his doctrine problematic is its language, narrow and excessive, which might lead astray the simple souls. Indeed, the use of suitable language in the articulation of doctrine is a constant concern in Gerson's work ${ }^{59}$. The form must betoken the content's orthodoxy: a sober and "common" language conveys the humility which alone guarantees a message inhabited by divine grace. Gerson adds another qualification to Ubertino's statements: if it is true that Christ had perfect knowledge of his future Passion from the moment of his conception, this knowledge did not express itself in physical pain. Indeed, as the Gospels teach us ("Jesus was increasing in wisdom and in years": Luke 2, 52), Christ's physical and emotional experience responded to the gradual acquisition of new knowledge ( $5^{\text {th }}$ truth $)^{60}$. Furthermore, to hold that Christ's

sustinuit; partim pronosticum et figurativum, tam eorum que debebat in continenti sustinere in corpore proprio, quam successu temporis in corpore mistico electorum in quibus et ipse tunc patiebatur." Arbor vitae, IV.9, 308a. See also Martínez Ruiz, De la dramatización 342344; F. Callaey, L'idéalisme franciscain spirituel au XIVe siècle. Etude sur Ubertin de Casale (Louvain 1911) 87-89; henceforth: Callaey, L'idéalisme franciscain.

56 Arbor vitae, IV.9, 309b. See also Martínez Ruíz, De la dramatización 346, 520-530.

57 The insistence on the interior suffering of Christ is not particular to Ubertino. It constitutes a characteristic feature of spiritual Franciscan devotion. We find it notably in Olivi and Angela of Foligno. Martinez Ruiz has noted the parallels between Ubertino and Olivi in the interpretation of Matthew's passage: De la dramatización 344-345.

58 "[3a veritas]: Christus ut beatificatus in animam nunquam sensit dolorem pro peccatis hominum quorumcumque nec pro poenis alienis aut propriis in corpore suo vel in portione rationis inferiori susceptis. Patet quia in beatitudine non est luctus neque dolor." Glorieux, 2.264 .

59 See for example De examinatione: Glorieux, 9.466, concerning Raymond Lull's unusual language. On this topic, see also Contra curiositatem studentium, cons. 6: Glorieux, 3.244245.

60 " $\left[5^{\mathrm{e}}\right.$ veritas]: Christus ab instanti suae conceptionis quamvis habuerit clarissimam notitiam et apprehensionem suae passionis futurae, et quod animam dulcissimae matris pertransierit gladius acerbissimae passionis, ipse tamen non habuit hujusmodi passionis experimentalem in corpore qualem habuit dum cepit taedere et maestus esse et consequenter ab agonia 
knowledge of his future Passion was manifested physically from conception compromises the voluntary character of his sacrifice. For according to the divine will and thus to faith, Christ did not suffer necessarily as the result of a physical determination ( $7^{\text {th }}$ truth) ${ }^{61}$.

Concerning Ubertino's problematic Mariological statements, the Arbor vitae maintains that Mary's sorrow ${ }^{62}$ increased according to the knowledge she had of her Son and his mission ${ }^{63}$. Mary is in Ubertino's view the paradigm of perfect love and the most accomplished realisation of the vita crucifixae Iesu. ${ }^{64}$ In this respect, she enjoys as many graces as her union to her crucified Son is tight ${ }^{65}$. The close connection between Mariology and Christology leads Ubertino to hold an extreme version of the Immaculist thesis. Insofar as she had once formed one body with her Son and did not experience any sensual appetite, Mary was spared of all bodily corruption. Christ wanted to protect his mother from the ignominy of carnal corruption; and since it was suitable to protect her on the grounds of filial respect and it was in his power to do so, Christ had to do it ${ }^{66}$.

Gerson's primary concern is to correct Ubertino's temerity in pretending to deal with Mary and Christ on an equal footing. First of all, Mary's sorrow was undergone not voluntarily, as it was the case with Christ, but by reason of the sinful nature she had inherited as descendant of the Adamic race. As any other person conceived in the natural way, Mary had in principle to undergo the sorrow resulting from original sin, unless exempted by the intervention of supernatural grace (10 th truth $)^{67}$. On the other hand, in choosing to protect his mother from original

usque ad exspirationem pertulit et sensit. Veritas illa pro prima parte patet ex praecedentibus; sed secundam concedit communis omnium doctorum approbatorum scola, quia sic et non aliter videtur posse salvari illud Lucae quod Jesus proficiebat aetate et sapientia. Experiebatur enim per assiduum crementum notitias novas rerum, et si novas notitias sensuales, ita novas tristitias aut delectationes isto modo." Glorieux, 2.264-265. See also the 14th truth: Glorieux, 2.267 .

61 "[7a veritas]: Christus noluit quod beata mens sua ut sic, susciperet influxum partis inferioris aut sensualis, et hoc passibiliter et poenose, licet bene praecognoverit poenas sensus intellectualiter immo et gaudiose; alioquin non fuisset passus voluntarie, desideranter et consonne voluntati divinae. Veritas haec est catholica et concessa." Glorieux, 2.265. See also truths 6 and 8 .

62 Ubertino draws here from the Franciscan tradition, notably the Quaestio that Olivi devotes to Mary's sorrow. For Olivi, see D. Pacetti, Petri Ioannis Olivi O.F.M. Quaestiones quatuor de Domina 4 (Quaracchi 1954) 58-88: "Quaeritur an Virgo doluerit tantum in passione Christi quod nullum sesibile gaudium habuerit tunc de aliquo, aut e converso longe plus habuerit de gaudio quam de dolore". See also Martínez Ruíz, De la dramatización 552558.

63 See Arbor vitae, IV.15, 322a; also 321b.

64 Arbor vitae, IV.15, 324a.

65 Arbor vitae, IV.15, 322a. See also Martínez Ruíz, De la dramatización 563-568.

66 Arbor vitae, IV.40, 404b-405a.

67 "[10a veritas]: Christus voluit dilectissimam matrem suam dolores et poenalitates hujus vitae destitutae suscipere, nedum voluntarie pure sicut Christus suscepit, sed ex conditione naturae viatricis descendentis ab Adam et cum necessitate contrahendi originale peccatum sicut alii per generationem viri et mulieres concepti, nisi gratia supernaturalis praevenisset 
sin, Christ does not grant her equal dignity to his own, but the one which suits her condition as a creature. Unlike her Son, who did not incur original sin because of his virgin birth, Mary was rather rescued from a sin already incurred. While subscribing to the Immaculist thesis ${ }^{68}$, Gerson attempts to moderate Ubertino's statements: the universality of Christ's redeeming act requires that his mother be freed from sin with the rest of humanity (11 th truth) ${ }^{69}$. In this respect, and considering the space he devotes to it (ten "truths" over twenty-four), Gerson finds particularly problematic the logical connection Ubertino establishes between fittingness and necessity as he maintains that because it is becoming for Christ to honour his mother and he has the power to do so, he must do it. This argument not only jeopardises divine freedom, but is in addition fallacious. Unlike created will, whose action follows the good presented to it by the intellect, what God chooses to do by his free and rightful will becomes for that same reason suitable. Creatures are ordered to the final good, not the other way around $\left(17^{\text {th }} \text { truth }\right)^{70}$. If Christ granted his mother as many graces as he saw fit $\left(12^{\text {th }} \text { truth }\right)^{71}$, he could have con-

casum in hoc originalis culpae praecipitum. Factum est perinde consequenter in Maria quantum ad poenas naturae debitas ex originali sicut in aliis sanctificatis aut baptizatis nisi quantum ex privilegiis et gratis spiritualibus fuit adjuvata. Veritas haec probabili pietate cordis credi potest."

68 The young Gerson played an important role during the controversy which opposed the Dominican Jean Monzon to the University of Paris in 1388 on the question of the Immaculate Conception. See Glorieux, 10.7-24 for Gerson's treatise against Monzon. See also Gilbert Ouy, La plus ancienne œuvre retrouvée de Jean Gerson: le brouillon inachevé d'un traité contre Jean de Monzon, in: Romania 83 (1962) 433-492; Id., Discovering Gerson the $\mathrm{Hu}-$ manist, in: A Companion to Jean Gerson, ed. Brian P. McGuire (Leiden, Boston 2006) 77132, esp. 96-104.

69 "[11a veritas]: Christus praeservando matrem suam ab originali non ob hoc dedit dignitatem aequalem sibi ipsi, etiam secundum humanitatem viatricem. Ratio: quia nunquam Christus habuit necessitatem originale peccatum contrahendi quia non descendit per naturalem propagationem; propterea ratio sumpta ex hac aequalitate quod Maria contraxit originale prorsus est invalida; similiter et altera quod Maria non indiguisset redemptione; nec valeat Apostoli consequentia: Christus pro omnibus mortuus est, ergo omnes mortui sunt [II Cor. $5,14]$; hoc inquam argumentum potius est ad oppositum, quia si Christus fuit omnium perfectissimus redemptor, mortem pro omnibus sustinens, decuit quod matrem perfectissime redimeret; hoc autem non potuit convenientius fieri quam praeservando ne caderet potius quam jam lapsam relevaret. Veritas haec probabilis est et pia; super qua mirum est quod nonnulli volentes Virginem benedictam supra limites honorare, praedicant nihilominus quod contraxit originale, sicut unus de quo infra." Glorieux, 2.266. See also truths 19 and 21: Glorieux, 2.268 .

70 "[17a veritas]: Christus potuit et potest multa facere et hoc decet eum; ergo fecit aut faciet. Consequentia talis quae fit a multis, saepe fallit per fallaciam petitionis principii, quia videlicet praesupponit in minori propositione quod est aeque ignotum vel ignotius quam principale. Ratio: quia nihil decet Deum facere nisi secundum quod vult fieri recte, per oppositam considerationem ad voluntates creatas quae ideo volunt agere quia praesentatur eis aliquod objectum sub ratione boni aut convenientis; et ideo agunt quia videtur eis bonum, et non ideo illud est bonum aut decens, quia agunt. Causa est: non enim sunt regulae primae sed regulatae a prima bonitate." Glorieux, 2.267 .

71 "[12a veritas]: Christus contulit matri suae ab initio et consequenter illas et tantas gratias quas et quantas cognovit esse convenientes secundum ordinem suae sapientiae; et in hac veri- 
ferred, by virtue of his absolute power, other privileges than the ones he actually conceded to her (15 th truth $)^{72}$. It is both presumptuous and a temerity to judge what is fitting for God to do, for it is not for man to inquire about the hidden design of the divine will. In characteristic fashion, Gerson concludes with a plea for prudence and moderation: "let human chatter place the finger on its mouth and be contented with its limits"73.

The second list of truths deals with the reception of grace in the mystical union, more specifically with the following question: how to recognise the true gift of the Holy Spirit among the false inspirations which are not of divine origin ${ }^{74}$ ? According to Gerson, even if grace often manifests itself by external feelings up to the profusion of tears, one must be sceptical about certain spiritual exaltations ${ }^{75}$. This kind of excess "is not a perfection in itself, but an instrument of perfection" $"$. In-

tatis soliditate debet esse contentus in summo quilibet christianus quantumcumque sibi devotus. Attamen quia particularizata praeconia magis ad devotionem movent aliquando pios animos, placet aliquas subjungere veritates super istis ad utrumque libratas." Glorieux, 2.266. 72 "[15a veritas]: Christus potuit dare multas gratias tam humanitati suae quam dilectissimae matri pure gratis, quas tamen actualiter et de facto non contulit. Et oppositum asserere est falsum et temererium, immo haereticale. Patet haec secunda pars quia Christus potuit ab utero matris suae dare de potentia absoluta impassibilitatem suae humanitati qualem habuit de praesenti; similiter et matri suae, saltem post conceptionem benedictae prolis suae; et constat certa fide quod neutrum fecit." Glorieux, 2.267.

73 "[23a veritas]: Christus si perquiritur a talibus cur matrem suam honoravit in istis gratiis et non in omnibus aliis quibus poterat, respondeat: quis es o homo ut investiges sensum Domini, quis es ut consiliarius ejus fias, quis es ut praesumas dicere cur ita facis? Ponat igitur humana loquacitas digitum ori suo et terminis suis contenta sit." Glorieux, 2.269. A veiled endorsement of negative theology?

74 "[3a veritas]: susceptio Israël pueri Dei quamvis possit agnosci per probabiles conjecturas ab illo qui suscipitur, non tamen evidenter revelatione super hoc non habita ..." Glorieux, 2.270. Also: "[4a veritas]: susceptio per gratiam gratum facientem non semper latet ad certum quatenus impleamus illud: servite Domino in timore [Luc 1,53] et ne servitus moesta et gravis videatur, exsultate ei. Verum ne sit exsultatio dissoluta jungitur: cum tremore, et subsequitur: apprehendite disciplinam." Glorieux, 2.270.

75 "[5a veritas]: susceptio gratificans videtur hic in via potissimum cognosci per cordis sentimenta, sumendo cor pro toto ejus triclinio secundum triplicem coenaculum, mentis scilicet et orationis et animae juxta tractata super psalterii Mariae dechacordi fidicula [i.e. Collectorium super Magnificat: Glorieux, 8.461-462]: dispersit superbos mente cordis sui; praesentiam verbi, inquit Bernardus, ex motu cordis accepi. Sic alii omnes contemplationi vacantes signa tradiderunt, nunc haec, nunc illa, multiplicia valde variaque cordis sentimenta usque ad profusionem lacrimarum; de quibus non est hic dicendum per singula sed sub cautelae generalis monitione sistendum." Glorieux, 2.270.

76 Glorieux, 3.14-15. For Gerson's scepticism regarding this kind of excess, see De orationibus privatis fidelium: Glorieux, 10.137-138. See also Hobbins, Gerson on Lay Devotion 66. In this respect, Gerson criticises the "ramblings and heresies" caused by assiduous meditation on Christ's Passion, notably in the cercles of fraticelli and Begards: "[12a veritas]: susceptio gratificans dum visa est apud multos colligi per mediationem assiduam passionis Jesu Christi, causavit de per accidens ex superbo usu suo hominibus de utroque sexu durae multum austeritatis in vita, plurimas haereses et derilamenta; et tandem aliqui ex eis in abominandissima carnis sentimenta prolapsi sunt et innominaliter maculati. Sunt in exemplum veteres et novi Fraticelli et fraticellae, Begardi et Begardae, de quibus non est hic dicendum per singula.” Glorieux, 2.272 . 
deed, divine grace can very well act upon the soul without any sensible manifestation, as is the case with baptised children or the rightful as he sleeps ${ }^{77}$. To pretend that one can determine whether a person is saved or damned according to sensible signs reveals "a very perverse temerity and an intolerable arrogance"78. Especially if it concerns women:

[10th truth]: if it is dangerous for any man to attempt to understand out of curiosity the grace that comes at reception, it is all the more dangerous for women, who are particularly vehement and tenacious in understanding and who have a reckless eagerness in penetrating the secrets of God. They are also particularly inclined to errors and illusions; and they sometimes take pleasure in God as a lover in fornication. Why? Indeed, because they only seek the pleasure of the feelings of God himself and not the production of good deeds 79 .

The De examinatione had already warned us against female visionaries: following saint Paul's lead (I Tim. 2, 12), Gerson maintains that all doctrine professed by women must be considered as suspect, as long as the relevant doctrinal authorities have not examined it with the required attention. As way of exemplum, Gerson refers to an anecdote from the life of the Avignonese pope Gregory XI. Before dying, the pope warned those assembled around his deathbed to be wary of any man or woman presenting themselves as visionaries under cover of true religion. For he was himself seduced by such people when, wrongly dismissing the counsel of his own cardinals, he left for Rome thus precipitating himself and the Church in the schismatic crisis ${ }^{80}$. In the same spirit, Gerson warns his reader of the dangers

77 "[6a veritas]: susceptio gratificans stat frequenter sine quibuscumque sentimentis actualibus cordis. Patet in pueris baptizatis, patet in justis dormentibus aut in solo gratiae habitu sine quavis actione gratis Deo simul et accpetis." Glorieux, 2.270.

78 "[7a veritas]: susceptio gratificans saepe fit et est in suo actu intrinseco et formali elicito vel exterius imperato, sine perceptibilibus certitudinaliter gratiae sentimentis in corde vel sensibus. Patet in activis per varia distractis, nullam in corde suo sentimentorum spiritualium mollitiem aut liquefactionis suavitatem habentibus; immo maxima christianorum pars vix alias servit Deo; quos judicare damnandos vel extra statum salutis ob hoc esse, perversissimae est temeritatis et intolerabilis arrogantiae apud illos qui sentimentis hujusmodi crebro gaudent, qui suam in illis salutem totam ponunt et gloriam. Sed heu saepe quam profunde fallit eos stulta praesumptio cordis sui; quam frequenter illuduntur a demonio meridiano, quia superbia meretur illudi; denique meretur etiam dum Eucharistiam suscipit, illud imprecatum per psalmistam: fiat mensa eorum coram ipsis in laquem [Ps. 68, 23], cum ceteris quae sequuntur sub trinodecimo numero maledictis." Glorieux, 2.270-271. The 11th truth continues along the same lines: Glorieux, 2.271.

79 "[10e veritas]: susceptio gratificans si quaeritur periculose cognosci per curiositatem in quolibet homine, tamen hoc maxime periculosum est in feminis quae sunt fortissime et tenacis apprehensionis et aviditatis temerarie penetrandi secreta Dei; sunt et ad lapsus et ad illusiones proclivissimae; diligunt tales aliquando Deum velut adulterum concubitu fornicatio. Quare? Sane quia delectationem sentimentorum ipsius Dei solam, non prolificationem bonorum sunt operum requirentes..." Glorieux, 2.271-272. See as well De examinatione doctrinarum, II.: Glorieux, 9.468.

80 Glorieux, 9.466-470. On Gerson and women, see: Anderson, Gerson's Stance on Women 293-315; Dyan Elliot, Proving Woman: Female Spirituality and Inquisitional Culture in the Later Middle Ages (Princeton, NJ 2004); Jo Ann McNamara, The Rhetoric of Orthodoxy: Clerical Authority and Female Innovation in the Struggle with Heresy, in: Maps of Flesh and 
involved in Ubertino's enthusiasm regarding female visionaries ${ }^{81}$. As we learn from the first Prologue of the Arbor vitae, Gerson is here alluding to three women in particular: Cecilia of Florence, who initiated Ubertino to the secrets of contemplation and the mysteries of the heart; Angela of Foligno, who taught him "the angelic life on earth"; and Margaret of Castello, known for her austerity and contemplative rapts and who lent him precious help in writing 82 .

Gerson's mistrust on women is rooted, not as much in a clerical misogyny which would anyway need to be qualified ${ }^{83}$, but in the broader context of new forms of devotion and doctrinal authority. Indeed, spiritual movements and their followers, be it men or women, represented a challenge to the theologians' authority, if not their role and position in society. Such movements enjoyed a real influence on simple believers and often established themselves as counter-authorities. They advocated a social ideal in which university theology no longer played any role in the spiritual guidance of the faithful - indeed, Ubertino's spiritual guides are not theology masters experts on doctrine, but women inspired by an equal desire to share as intimately as possibly in Christ's suffering. Ubertino's ideal belongs to this milieu, in which the adherence to faith and spiritual vitality are not guaranteed by science or the ecclesiastical hierarchy, but by the intimate experience of a personal union with Christ in the imitation of his life and Passion. From this viewpoint, the true sign of grace is not a judicious and expert opinion, but personal charisma, piety and moral rigorism.

In response, Gerson disapproves of Ubertino's presumptuousness throughout his work as he acts as arbiter on doctrinal matters. Theologically incompetent and running against all recognised criteria of doctrinal truth, Ubertino is a zealous but ignorant judge. It is not truth and humility that guide him, Gerson adds, but vanity ${ }^{84}$. As an example, the ex-chancellor mentions Ubertino's outrageous statements regarding the lot reserved to unbaptised children. Against the common

Light: The Religious Experience of Medieval Women Mystics, ed. U. Wiethaus (Syracuse, NY 1993) 9-27.

81 "Rursum per illum nimis extollitur statu sille qualem notat se tenuisse conformiter ad feminas aliquas, magnae ut asserit elevationis et prophetici spiritus, quarum tamen doctrinae sunt suspectae, jubente Apostolo qui habebat spiritum Dei: mulierem docere non permitto." Glorieux, 2.273.

82 Arbor vitae, Prol. I, 3b-7b. See also Hobbins, Gerson on Lay Devotion 62-64.

83 Indeed, Gerson often reveals a profound respect for the spiritual power of women. It is the case in his commentaries on Marguerite Porette's "Mirror", his assessment of Ermine of Rheims's visions, and his professed admiration for Agnes of Auxerre, to whom he dedicated La mendicité spirituelle. See Hobbins, Gerson on Lay Devotion 64.

84 "Viderit quo zelo, viderit quo aedificationis auditu fructuoso, multi judicant quod non secundum scientiam; attento quod pro cognomine vult nominari maximus peccatorum; qualiter ergo non prius auferebat trabem de oculo suo? qualiter obsurduerat ad illud probrum: medice cura teipsum? diceret quod ex humilitate sic judicari vult; sed si non ex veritate quid nisi vanitas et damnabilis vanitas? Si ex sensus intimitate se ita judicari volebat, attenderit ne plus Paulo, immo Maria, praecellat in hac laude ut non jam ipse maximus aut primus esset peccatorum quia non humilior plus omnibus." Glorieux, 2.273. In this respect, see also Contra curiositatem studentium: Glorieux, 3.238. 
opinion, the Franciscan pretends that innocent children will be eternally damned and suffer physical pain through fire. Their sentence will be however mitigated since they have not incurred any sin other than the original sin inherited through their parents ${ }^{85}$.

Advanced in a spirit of singularity and utter temerity, Ubertino's scandalous statements are not, in Gerson's view, worthy of any credibility. It is only in complying with the theological tradition that they can aspire to some legitimacy, and even then it is best to leave the last word to the accredited doctors. Gerson concludes his letter with a suggestive image. Borrowing here and there from the theological tradition as he surreptitiously takes entire passages from Bonaventure's Beviloquium for his own benefit, Ubertino resembles Aesop's crow who adorns his wings with feathers belonging to other birds ${ }^{86}$. Simple believers and ill-advised readers fall into the trap and let themselves be deceived by the false plumage. But the theologian, endowed with sharper insight, is able to detect the stratagem and discern the feathers belonging to other birds. The moral of the fable: it is better to bathe in "the manifest and common waters of the wisdom approved by the doctors" than in "the furtive waters" of questionable and obscure doctrines ${ }^{87}$.

$* * *$

The significance of Gerson's model of theological authority lies in an aspect which the specialists often see as a weakness ${ }^{88}$, but where I recognise its force, namely the ambivalent attitude Gerson reveals towards the spirituality of his time. Assiduous commentator of the pseudo-Denys, he has both a very developed sense of hierarchical order and a mystical sensibility which brings him closer to new forms of lay devotion. Gerson's model of theological authority encloses in my view a new understanding of the responsibility of the theologian which embraces both sides of

85 "Quidquid de parvulis affirmare praesumit contra communem omnium doctorum scolam, quod pueri in limbo non baptizati acriter puniantur poena ignis sensibili ponereque videtur quod in hac afflictione carent omnino rationis judicio et libertate arbitrii." Glorieux, 2.273-274. For Ubertino, see Arbor vitae, III.2, 139b-143b, esp. 142b: "Ideo teneo cum Augustino, Gregorio et cum sacro textu sententiae Jesu Christi (Math. 25), quod totum corpus reprobum in parvulis et in grandevis in aeterno igne cum diabolo cruciabitur, licet distinguam sicut distinguit Augustinus in Enchiridion quod ibi est in cruciatibus gradus pro gravitudine et multiplicatione peccatorum." Denys the Carthusian, mystical theologian and author of numerous works on spirituality, criticised Ubertino on the same point and for the same reasons. See Doctoris Ecstatici D. Dionysii Cartusiani In IV libros Sententiarum, Opera omnia 22 (Tournai 1904) 451. See also Callaey, L'idéalisme franciscain 91-93.

86 "Saepe vero magnas partes excerpit et rapit in propria forma tacitis auctorum nominibus; nescimus si par esse voluerit Aesopi corniculae, plumis aliarum volucrum se ornantis. Creber fuit apud istum Bonaventura cum suo Breviloquio, sed vix nominatus ex illo. Multi praeterea sunt sermones sub contextu suae locutionis quos in forma legimus apud libros alios non modicae vetustatis." Glorieux, 2.274 .

87 "Habent enim aquas patentes et publicas sacrae sapientiae per doctores approbatos; non est necesse ipsos obedire meretriculae dicenti: aquae furtivae dulciores sunt et panis absconsus suavior." Glorieux, 2.274.

88 See for example Hobbins, Gerson on Lay Devotion 74-75. 
our author's dichotomy. Sensible to the loving knowledge of God and at the same time spiritual guide to the faithful, the theologian is best equipped to encourage popular devotion while channeling it in favour of the preservation of orthodox doctrine as the Church understands it. Pastoral care rallies concern for reform, in a common effort to promote the return to a Church governed by the Spirit.

\section{Summary}

On 18 September 1426, in a letter addressed to the Celestine Jean Bassandi, Jean Gerson develops a long criticism of the Arbor vitae crucifixae Iesu, Ubertino de Casale's well-known work. Gerson's criticism assumes the form of a treatise, of normative intent, on the subject of Christ's Incarnation and religious perfection. The ex-chancellor's correspondence with the Celestines concerning Ubertino's work has attracted the attention of specialists mainly on two counts: firstly, as a witness to an internal development in Gerson's theory of mystical theology (it is notably the case of the 1425 letter to Gerson's brother Jean the Celestine); secondly, as an example of the ecclesiastical authority's censure mechanisms and their mostly negative impact on popular religion. By focusing on the 1426 letter, this paper attempts to offer a different interpretation of the purpose and significance of Gerson's view of and relation to popular piety. Indeed, Ubertino's Arbor vitae enjoyed much popularity as a devotional work in the context of $15^{\text {th }}$-century spirituality. The alternative model of religious perfection purported by the Franciscan witnesses a normative pluralism underlying the correspondence between Gerson and Bassandi. Far from a one-way form of influence coming from the higher strata of the hierarchy down to the non-initiated, what seems to motivate Gerson is a pastoral, rather than purely doctrinal, concern to keep the "simple ignorant of theology" away from doctrinal ambiguities and innovations that could lead astray an otherwise solid faith. Assuming the role of a spiritual director keen on reaching his brethren's hearts according to their social status and mode of life, Gerson shows more kinship with humanists like Petrarch than with the university establishment that he is generally seen to represent. 